\title{
Tsafon
}

Revue d'études juives du Nord

$75 \mid 2018$

Exil des langues - Langues d'exil

\section{Robert Bober, Vienne avant la nuit}

\section{Danielle Delmaire}

\section{OpenEdition}

Journals

Édition électronique

URL : https://journals.openedition.org/tsafon/724

DOI : $10.4000 /$ tsafon.724

ISSN : 2609-6420

\section{Éditeur}

Association Jean-Marie Delmaire

\section{Édition imprimée}

Date de publication : 1 juin 2018

Pagination : 184-186

ISSN : 1149-6630

\section{Référence électronique}

Danielle Delmaire, «Robert Bober, Vienne avant la nuit », Tsafon [En ligne], 75 | 2018, mis en ligne le 06 mai 2019, consulté le 24 juin 2021. URL : http://journals.openedition.org/tsafon/724 ; DOI : https:// doi.org/10.4000/tsafon.724

Ce document a été généré automatiquement le 24 juin 2021.

Tsafon. Revues d'études juives du Nord 


\title{
Robert Bober, Vienne avant la nuit
}

\author{
Danielle Delmaire
}

\section{RÉFÉRENCE}

Robert Bober, Vienne avant la nuit, Paris, P.O.L éditeur, 2017, 155 p., 32,90€

1 Livre abondamment et agréablement illustré (photos, dessins, reproductions notamment des œuvres d'Ilex Beller sur le sthetl), Vienne avant la nuit donne le contenu $\mathrm{du}$ film de Bober portant le même titre. On y retrouve les photos d'Ellis Island, de Vienne, du cimetière où Bober cherche obstinément la tombe de son arrière-grandpère, les photos de sa famille et particulièrement, en ouverture à l'ouvrage, celle d'un juif pieux, couvert du talith et de la kippa, la barbe blanche et la tête tenue dans la main gauche, les yeux perdus dans une profonde réflexion surgie de la lecture du livre tenu de la main droite. C'est Wolf Leib Fränkel, l'arrière-grand-père qui voulut fuir la Pologne pour se réfugier aux USA mais le contrôle à Ellis Island le refoula pour cause de maladie ! Il revint en Europe pour s'installer à Vienne, la Vienne d'avant la guerre.

Bober sort de l'oubli son arrière-grand-père, dont il conserve précieusement les chandeliers fabriqués de sa main d'adolescent, sa famille dont il possède encore une photo d'une vingtaine de personnes - la moitié disparue dans la Shoah. Il cherche dans le passé de Vienne, d'avant la nuit, les foules acclamant l'entrée des troupes nazies dans la ville, l'insouciance face aux exactions commises contre les juifs. Tout cela appartientil au passé, au temps d'avant ? Lorsque Bober propose, à des Viennois des années 2010, la lecture de journaux d'avant-guerre, ces derniers manifestent une certaine perplexité voire incrédulité à l'égard de ces informations d'avant la nuit. Bober remarque encore que le maire Lueger élu sur un programme antisémite, à la fin du XIXe siècle, reste à l'honneur dans la Vienne de maintenant : un boulevard portait encore son nom en 2012 et « un monument le célèbre encore sur une place viennoise » (p. 94).

3 Avec Vienne avant la nuit, Robert Bober complète son abondante œuvre de documentariste et d'écrivain, reposant essentiellement sur le sort des juifs avant, pendant et après la guerre. Né à Berlin, en 1931, d'un couple juif originaire de Pologne, 
Bober vécut ses premières années à Paris, dès 1933. Il échappa aux rafles et sa scolarité fut écourtée, n'allant pas au-delà du certificat. Il exerça divers métiers : tailleur, potier avant de rencontrer, dans les années 1950, Truffaut dont il devint l'assistant. Sa carrière commença à partir de cette collaboration. Il fut également le complice de Georges Perec pour le film : Récits d'Ellis Island. Tandis que son premier roman : Quoi de neuf sur la guerre (1993) obtenait le prix du Livre Inter en 1994. 